\title{
The Use of Reflective Journal as a Tool for Monitoring of Metacognition Growth in Writing
}

\author{
https://doi.org/10.3991/ijet.v15i11.11939
}

\author{
Dina Ramadhanti, A. Syukur Ghazali $\left.{ }^{(}\right)$, Muakibatul Hasanah, Titik Harsiati \\ Universitas Negeri Malang, Malang, Indonesia \\ syukurghazali.fsumegmail.com \\ Diyan Permata Yanda \\ STKIP PGRI Sumatera Barat, Padang, Indonesia
}

\begin{abstract}
A reflective journal is used as a technique of self-reflection in the learning process. By integrating the process of metacognition, a reflective journal guideline was developed to knowing students' metacognition growth in writing. The reflective journal guidelines are designed in the form of self-questioning to make it easier for students to express their metacognition processes during their writing assignments. The metacognition process consists of three, namely awareness, evaluation, and regulation. The reflective journal guidelines that were compiled was given to 50 students. Before writing a reflective journal, students are asked to work on the task of writing explanatory texts. Students monitor the metacognition growth of while writing the explanatory text using reflective journal guidelines. Research findings show that reflective journal guidelines can be used to monitor the growth of students' metacognition in writing. Both students who are used to writing and who are not accustomed to writing can express their writing experience by answering questions in the reflective journal guidelines. This finding also shows that teachers must always encourage students to always write reflective journals in order to monitor metacognition growth in writing, ranging from raising awareness about knowledge and task completion efforts, monitoring the quality of the results obtained, and fostering the habit of planning, setting goals, and apply certain strategies in completing tasks. Students who are used to writing reflective journals in the learning process will be able to develop their writing skills and will become independent learners.
\end{abstract}

Keywords - Reflective journal, monitoring, metacognition, writing

\section{Introduction}

The main feature of reflection in the learning process is that learning is based on previous experience [1]. The reflection is focused on students, aspects of context, skills and learning strategies. Reflection also facilitates and integrates knowledge, experience, and ongoing actions [2]. All of that is recorded by students in the most powerful self-evaluation tool called the reflective journal [3]. Writing a journal is seen as a way to record personal thoughts, daily experiences, and insights that continue to develop. 
The process often evokes conversations with yourself, other people, or even other people imagined [4]. Reflection gives students the opportunity to think and reflect on their learning and note the obstacles they might face during the learning process [5], including pedagogical changes, reflections on past experiences, changes in attitude, selfawareness, personal experiences, and concerns about future careers [6]. Reflective journals can also give students the opportunity to reflect on their practices and implications for social change and personal empowerment [7]. In short, reflective journals can facilitate and assess reflection [8].

Reflective journals can develop metacognitive awareness and conscious control over students learning strategies [9]. Increased metacognitive awareness occurs because reflective journals offer stimuli to think about students' cognitive processes [10]. Reflective journals can also develop metacognitive skills, namely self-assessment, and selfmanagement [3]. Self-assessment is the ability to assess one's own cognition while selfmanagement is the ability to manage one's own cognitive development. As a means of developing management skills, reflective journal writing has the potential for personal, professional development, and improving performance-based practices [11]. With this management skill, a person will become more aware of themselves, others, and their work situation.

Reflective journals are useful for developing metacognitive awareness and can also be useful for developing writing skills [12], for example, it can improve the ability to write narrative texts [13] and various other types of writing. Journals not only teach students to write but also encourage them to share their experiences and ideas [6]. Currently, through reflective journal writing activities, writing activities are seen as tools to elaborate and produce knowledge [14]. To improve writing skills, students are required to write journals not only when monitoring the writing process, but also when understanding written materials. This journal provides benefits for developing ideas and increasing the cohesion and coherence of texts written by students [15]. Journal writing is useful in language learning in aspects of remembering, encouraging oneself, awareness of completing assignments and developing metacognition [16]. Reflective journals are needed both in the classroom and outside the classroom to develop selfawareness, critical thinking skills and to facilitate certain learning [9]. Reflective journals provide the right tools to help students to develop greater awareness about their learning strategies and will help them become independent learners [9]; [17]. By using reflective journals, students can overcome the weaknesses of their metacognition in writing [18]. Reflections carried out using reflective journals are assumed to be able to help students become independent learners without relying on others if they have difficulty in writing, are aware of the benefits and strategies used, and are able to assess their own understanding when receiving certain information during writing. All that will be realized if teachers and students consistently use reflective journals to reflect on the teaching-learning process.

Reflective journal writing is considered the most effective technique in the writing process because it is useful for increasing motivation, creativity, and critical thinking skills among students [19]. The reflective journal used so far is in the form of short questions to find out the strengths and weaknesses that students encounter during the learning process. The short question was apparently not able to demonstrate the 
students' metacognition. They have not been able to present reflections that show the growth of their metacognition during the writing activities. The application of the journal will experience problems if given to students who are not accustomed to writing. In addition, students who are not critical will have difficulty expressing their ideas in journal writing because they are inexperienced and not accustomed to writing. If writing reflective journals becomes a habit, then the journal will have great potential as a practical approach to enhance learners' experiences and provide opportunities to connect theory and practice in learning [20].

One of the challenges of education is to provide strategies and processes that equip students and teachers to examine, criticize, and evaluate their own understanding and beliefs [21]. A reflective journal guideline designed by integrating metacognition processes is the right solution that is assumed to be able to answer these challenges. The process of metacognition generally takes place as long as someone does metacognition activities, namely awareness, evaluation, and regulation [22]. Awareness is an awareness of cognition, tasks, and self; evaluation is the assessment and monitoring of cognition; regulation is an effort to control and control the learning process to achieve meaningful results [23], [24], [25], [26], [27]. The three metacognitive processes are translated into reflective journal guides in the form of questions. These questions will be answered by students according to their experience while working on writing assignments. Students are required to do self-questioning which is all recorded in reflective journals. Self-questioning is students ask themselves to guide their performance before, during, and after the performance of the task. By doing self-questioning, students can increase self-awareness and control their thinking, increase retention of knowledge and long-term skills, increase the ability to apply and transfer knowledge and skills learned, and improve attitudes and motivation as a result of improved performance [28].

By integrating the metacognition process into the reflective journal guidelines, it is assumed that students can record and report all of their metacognition activities during writing. This reflective journal is assumed to be a powerful tool for monitoring metacognition growth in writing. Therefore, this article aims to explain the design of reflective journal guidelines oriented to the process of metacognition to monitor the growth of students' metacognition in writing.

\section{$2 \quad$ Method}

\subsection{Participants}

Participants in this study were students studying in the Program Studi Pendidikan Bahasa dan Sastra Indonesia, STKIP PGRI Sumatera Barat, Indonesia, class of 2016. Participants numbered 50 male and female students who were randomly selected. Participants are asked to fill in a reflective journal to monitor the writing process. They fill reflective journals while doing their writing assignments. The text written by students is explanatory text. 


\subsection{Research instruments}

The instruments used in this study, namely the explanatory text writing assignment sheet and reflective journal guidelines. First, the explanatory text writing assignment sheet that has been developed tested for validity in the writing process [29]. The explanatory text writing assignment sheet was developed based on the cognitive process theory [30] and explanatory text theory [31]. Second, reflective journal guidelines. The reflective journal guidelines were developed based on the theory of the process of metacognition, which consists of awareness, evaluation, and regulation. The reflective journal consists of 40 questions completed with four sub-questions to find out students' metacognition growth in writing explanatory texts (Appendix 1). Before being given to participants, reflective journals are examined by experts in the fields of language and linguistics teaching. Validation is done to check the validity of the instructions construction, the content construction, and the language suitability. In terms of instructions construction, the level of validity is very good $(100 \%)$. In terms of content construction, the validity level is very good (100\%). In terms of language suitability, the level of validity is very good (87.50\%). Therefore, based on the expert evaluation, the reflective journal guidelines developed is valid and can be used to monitor of students' metacognition growth in writing explanatory texts.

\subsection{Procedure}

Students work on writing assignments by following the work procedures listed on the writing assignment sheet. Students are given a reflective journal guide and fill in the journal while working on writing explanatory texts. Students write explanatory texts ranging from planning writing, developing writing frameworks, and evaluating writing. The process is visualized in the form of reflective journals. Through reflective journals, students reflect all activities carried out while completing writing assignments.

\section{Result}

Students record and report their metacognition growth in writing explanatory texts using reflective journal guidelines. Reflective journal guidelines are designed using metacognitive process theories, namely awareness, evaluation, and regulation.

\subsection{Awareness}

The awareness process occurs when students are dealing with assignments. Students will begin to think about the knowledge they have and the efforts that can be made to complete the task. During this process, students are required to be aware of their cognition, be aware of the task, and be aware of themselves. Awareness about cognition is distinguished by declarative knowledge, procedural knowledge, and conditional knowledge. If students have an awareness of cognition, tasks, and themselves during completing the task and are able to explain the process of awareness, it is assumed that 
he has been able to grow his metacognition awareness in writing. The question for the awareness process that was designed in the reflective journal guidelines is visualized in Table 1.

Table 1. Design of Reflective Journal Guidelines on Awareness Processes

\begin{tabular}{|c|c|c|}
\hline $\begin{array}{l}\text { Awareness } \\
\text { Processes }\end{array}$ & $\begin{array}{l}\text { Metacognition Activities } \\
\text { in Writing }\end{array}$ & Self-questioning \\
\hline \multicolumn{3}{|l|}{$\begin{array}{l}\text { Awareness about } \\
\text { cognition }\end{array}$} \\
\hline \multirow[t]{7}{*}{$\begin{array}{l}\text { Declarative } \\
\text { Knowledge }\end{array}$} & $\begin{array}{l}\text { 1. Be aware of the purpose of } \\
\text { writing }\end{array}$ & $\begin{array}{l}\text { 1. I realize the goal that I want to achieve in writing } \\
\text { explanatory texts, because }\end{array}$ \\
\hline & 2. Be aware of the topic & $\begin{array}{l}\text { 2. I'm aware of the topic that I will write in the form } \\
\text { of explanatory text, because }\end{array}$ \\
\hline & $\begin{array}{l}\text { 3. Be aware of the audience } \\
\text { needs }\end{array}$ & $\begin{array}{l}\text { 3. I realize the needs of the audience in writing this } \\
\text { topic in the form of explanatory text. Therefore }\end{array}$ \\
\hline & $\begin{array}{l}\text { 4. Be aware of the scope of } \\
\text { writing }\end{array}$ & 4. I'm aware of the scope that I will write, because \\
\hline & $\begin{array}{l}\text { 5. Be aware of the genre of the } \\
\text { text to be written }\end{array}$ & $\begin{array}{l}\text { 5. I'm aware of the genre of the text I will write, es- } \\
\text { pecially the explanatory text genre, i.e. }\end{array}$ \\
\hline & $\begin{array}{l}\text { 6. Be aware of the linguistic } \\
\text { structure that will be used }\end{array}$ & $\begin{array}{l}\text { 6. I'm aware of the linguistic structure that I need to } \\
\text { pay attention to in writing explanatory texts, for ex- } \\
\text { ample }\end{array}$ \\
\hline & $\begin{array}{l}\text { 7. Be aware of the writing pro- } \\
\text { cess will be carried out }\end{array}$ & $\begin{array}{l}\text { 7. I realize the process of writing explanatory texts, } \\
\text { that is by way of }\end{array}$ \\
\hline \multirow[t]{8}{*}{$\begin{array}{l}\text { Procedural } \\
\text { Knowledge }\end{array}$} & $\begin{array}{l}\text { 1. Be aware of how to plan } \\
\text { writing }\end{array}$ & $\begin{array}{l}\text { 8. I realized the way I had done while planning the } \\
\text { explanatory text writing, that is by way of }\end{array}$ \\
\hline & \multirow[t]{3}{*}{$\begin{array}{l}\text { 2. Be aware of how to produce } \\
\text { writing }\end{array}$} & $\begin{array}{l}\text { 9. I realized the way that I did while producing the } \\
\text { text, especially in choosing the vocabulary that I } \\
\text { used, that is by way of }\end{array}$ \\
\hline & & $\begin{array}{l}\text { 10. I realize the way that I do while producing text, } \\
\text { especially in arranging sentences according to their } \\
\text { structure and function so that the sentences and sen- } \\
\text { tence patterns that I present are more varied. The } \\
\text { way I do that is }\end{array}$ \\
\hline & & $\begin{array}{l}\text { 11. I'm aware of the way I have done while produc- } \\
\text { ing text, especially in the selection of lexical and } \\
\text { grammatical cohesion in connecting each part of the } \\
\text { sentence to a coherent paragraph, that is by way of }\end{array}$ \\
\hline & \multirow[t]{2}{*}{$\begin{array}{l}\text { 3. Be aware of how to connect } \\
\text { ideas }\end{array}$} & $\begin{array}{l}\text { 12. I realized the way that I had done while develop- } \\
\text { ing ideas in the form of explanatory texts, that is by } \\
\text { way of }\end{array}$ \\
\hline & & $\begin{array}{l}\text { 13. I realize the way that I do to connect ideas in } \\
\text { writing explanatory texts, that is by way of }\end{array}$ \\
\hline & $\begin{array}{l}\text { 4. Be aware of how to add de- } \\
\text { tailed writing }\end{array}$ & $\begin{array}{l}\text { 14. I realized the way that I did to add detail to my } \\
\text { writing, that is by way of }\end{array}$ \\
\hline & $\begin{array}{l}\text { 5. Be aware of how to revise } \\
\text { the text }\end{array}$ & $\begin{array}{l}\text { 15. I realized the way I did while revising the text, } \\
\text { that is by way of }\end{array}$ \\
\hline \multirow[t]{2}{*}{$\begin{array}{l}\text { Conditional } \\
\text { Knowledge }\end{array}$} & $\begin{array}{l}\text { 1. Critically considering spe- } \\
\text { cific writing assignments }\end{array}$ & $\begin{array}{l}\text { 16. I considered critically about the task of writing } \\
\text { explanatory texts, because }\end{array}$ \\
\hline & $\begin{array}{l}\text { 2. Determining the best skills } \\
\text { and strategies that can be used }\end{array}$ & $\begin{array}{l}\text { 17. I determine the best skills and strategies that I } \\
\text { can use in writing explanatory texts, for example }\end{array}$ \\
\hline
\end{tabular}




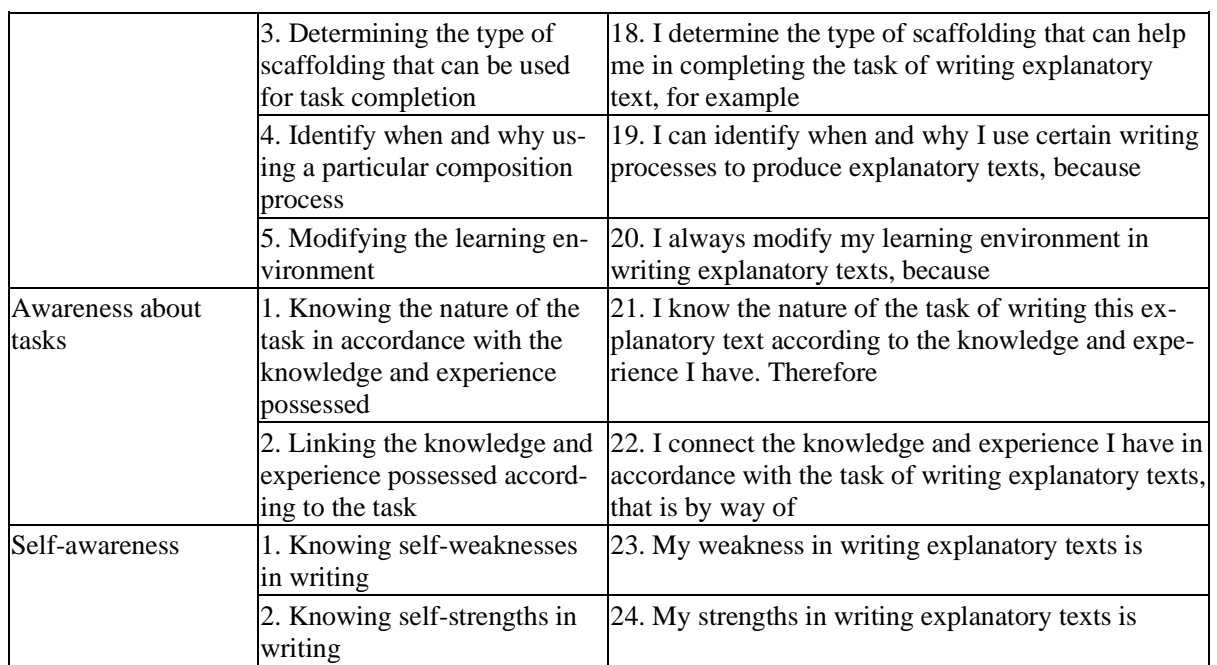

\subsection{Evaluation}

The evaluation process occurs when students begin to think critically about the knowledge they have and the quality of the results obtained. By realizing and understanding this evaluation, students are assumed to be able to grow awareness to assess their own performance in writing. By understanding the evaluation process, students will also understand the efforts that must be made when their performance has not shown maximum results. The question for the evaluation process designed in the reflective journal guidelines is visualized in Table 2 .

Table 2. Design of Reflective Journal Guidelines on Evaluation Processes

\begin{tabular}{|c|c|c|}
\hline $\begin{array}{l}\text { Evaluation Pro- } \\
\text { cesses }\end{array}$ & $\begin{array}{l}\text { Metacognition Activities } \\
\text { in Writing }\end{array}$ & Self-questioning \\
\hline \multirow{2}{*}{$\begin{array}{l}\text { Monitoring task } \\
\text { difficulties and } \\
\text { ease of learning as- } \\
\text { sessment }\end{array}$} & $\begin{array}{l}\text { 1. Understanding the level of difficulty } \\
\text { of writing tasks }\end{array}$ & $\begin{array}{l}\text { 25. I understand how difficult the task of writ- } \\
\text { ing explanatory texts. Therefore }\end{array}$ \\
\hline & $\begin{array}{l}\text { 2. Knowing every aspect of assessment } \\
\text { that must be considered in writing }\end{array}$ & $\begin{array}{l}\text { 26. I understand every aspect of the judgment } \\
\text { that must be considered while writing explana- } \\
\text { tory texts. Therefore }\end{array}$ \\
\hline \multirow{2}{*}{$\begin{array}{l}\text { Monitoring under- } \\
\text { standing and as- } \\
\text { sessment of learn- } \\
\text { ing }\end{array}$} & 1. Monitoring learning understanding & $\begin{array}{l}\text { 27. I always monitor my understanding while } \\
\text { writing explanatory texts, that is by way of }\end{array}$ \\
\hline & 2. Monitoring learning assessments & $\begin{array}{l}\text { 28. I made an assessment of the explanatory } \\
\text { text that I wrote, that is by way of }\end{array}$ \\
\hline $\begin{array}{l}\text { Monitoring of feel- } \\
\text { ing of knowing }\end{array}$ & $\begin{array}{l}\text { 1. Monitoring the level of awareness of } \\
\text { knowledge and experience that is diffi- } \\
\text { cult to remember in connection with } \\
\text { the task }\end{array}$ & $\begin{array}{l}\text { 29. I monitor a level of awareness of } \\
\text { knowledge and experience that is difficult to } \\
\text { remember in connection with the task of writ- } \\
\text { ing explanatory texts, that is by way of }\end{array}$ \\
\hline $\begin{array}{l}\text { Monitoring learn- } \\
\text { ing progress }\end{array}$ & $\begin{array}{l}\text { 1. Making and checking learning pro- } \\
\text { gress according to the assessment crite- } \\
\text { ria of learning outcomes }\end{array}$ & $\begin{array}{l}\text { 30. I make and check the progress of writing } \\
\text { explanatory text according to the evaluation } \\
\text { criteria of writing explanatory text, that is by } \\
\text { way of }\end{array}$ \\
\hline
\end{tabular}




\subsection{Regulation}

The regulation process occurs when students rethink plans, goals, and strategies that can be used. Students will reach the regulatory process if they already have an awareness of cognition, tasks, and themselves and have been able to evaluate their performance. In this regulation process, certain habits will arise in students to always plan, set goals, and set certain strategies in writing. If the process of regulation has been reached by students, by itself he will be able to monitor his performance in writing, not only in writing explanatory texts but also in writing various other types of texts. The question for the regulation process designed in the reflective journal guidelines is visualized in Table 3.

Table 3. Design of Reflective Journal Guidelines on Regulation Processes

\begin{tabular}{|c|c|c|}
\hline Regulation Processes & $\begin{array}{l}\text { Metacognition Activities } \\
\text { in Writing }\end{array}$ & Self-questioning \\
\hline \multirow[t]{3}{*}{$\begin{array}{l}\text { Regulation and control } \\
\text { of against planning } \\
\text { and learning task ob- } \\
\text { jectives }\end{array}$} & $\begin{array}{l}\text { 1. Controlling the learning } \\
\text { process according to plan- } \\
\text { ning and writing task objec- } \\
\text { tives }\end{array}$ & $\begin{array}{l}\text { 31. I have a habit of planning assignments and the } \\
\text { purpose of writing assignments as a form of control- } \\
\text { ling my learning process, that is by way of }\end{array}$ \\
\hline & $\begin{array}{l}\text { 2. Using the time effectively } \\
\text { and maximally in gathering } \\
\text { task materials }\end{array}$ & $\begin{array}{l}\text { 32. I have a habit of using time effectively to gather } \\
\text { writing material, because }\end{array}$ \\
\hline & $\begin{array}{l}\text { 3. Shows the best perfor- } \\
\text { mance in completing tasks }\end{array}$ & $\begin{array}{l}\text { 33. I have a habit to always show the best perfor- } \\
\text { mance in writing, that is by way of }\end{array}$ \\
\hline \multirow{2}{*}{$\begin{array}{l}\text { Regulation and control } \\
\text { of against strategy se- } \\
\text { lection and decision- } \\
\text { making efforts }\end{array}$} & $\begin{array}{l}\text { 1. Choosing, using, and re- } \\
\text { placing strategies that are ap- } \\
\text { propriate to the learning task }\end{array}$ & $\begin{array}{l}\text { 34. I have a habit of choosing, using, and replacing } \\
\text { the strategies I use according to my writing assign- } \\
\text { ments because }\end{array}$ \\
\hline & $\begin{array}{l}\text { 2. Knowing when and why } \\
\text { to change strategies for com- } \\
\text { pleting tasks }\end{array}$ & $\begin{array}{l}\text { 35. I have a habit of knowing when and why to } \\
\text { change strategies in completing writing tasks because }\end{array}$ \\
\hline \multirow{2}{*}{$\begin{array}{l}\text { Control over resource } \\
\text { allocation and regula- } \\
\text { tion of the use of time, } \\
\text { effort, learning steps, } \\
\text { and performance }\end{array}$} & $\begin{array}{l}\text { 1. Using effective time and } \\
\text { effort in completing tasks }\end{array}$ & $\begin{array}{l}\text { 36. I have a habit of using effective time and effort in } \\
\text { completing writing assignments, for example }\end{array}$ \\
\hline & $\begin{array}{l}\text { 2. Doing a series of steps to } \\
\text { write effectively to complete } \\
\text { the task }\end{array}$ & $\begin{array}{l}\text { 37. I have a habit of doing a series of steps in writing } \\
\text { effectively, for example }\end{array}$ \\
\hline \multirow{3}{*}{$\begin{array}{l}\text { Control and regulation } \\
\text { of against motivation, } \\
\text { emotions, and the en- } \\
\text { vironment }\end{array}$} & $\begin{array}{l}\text { 1. Having good motivation } \\
\text { in completing tasks }\end{array}$ & $\begin{array}{l}\text { 38. I have a habit of keep motivation in completing } \\
\text { writing assignments, that is by way of }\end{array}$ \\
\hline & $\begin{array}{l}\text { 2. Keeping emotions, } \\
\text { thoughts, and feelings during } \\
\text { task completion }\end{array}$ & $\begin{array}{l}\text { 39. I have a habit of keep emotions, thoughts, and } \\
\text { feelings while completing writing assignments, that is } \\
\text { by way of }\end{array}$ \\
\hline & $\begin{array}{l}\text { 3. Paying attention to the en- } \\
\text { vironment that can help and } \\
\text { support the convenience of } \\
\text { task completion }\end{array}$ & $\begin{array}{l}\text { 40. I have a habit of paying attention to the environ- } \\
\text { ment that can help and support the convenience of } \\
\text { completing writing assignments, that is by way of }\end{array}$ \\
\hline
\end{tabular}

\section{Discussion}

The use of reflective journals can help the achievement of purpose and learning outcome in Higher Education, namely: helping students to use appropriate learning 
strategies, helping students to monitor their learning process so they can identify the most appropriate strategy in certain situations, and help students to learn new strategies to replace old strategies that are less effective [9]. This is the reason that makes reflective journals used as a learning technique in higher education [12]. Another reason is that reflective journals can be used as a means to facilitate or assess learning [3] and as a means to promote and program students' learning [32]. Writing reflective journals in universities is considered useful in lifelong learning and must be practiced widely and sustainably [33]. Journals can be useful for identifying strengths and weaknesses, enhancing and evaluating actions correctly, examining students' experiences and assessing themselves [5], personal growth and development, intuition and self-expression, problem-solving, stress reduction and health benefits, reflection and critical thinking [4].

Reflective journals that are used excessively will make students feel bored and frustrated. So that student is not frustrated with the application of reflective journals, teachers must wisely encourage students to make reflective journals as often as possible and promote the effectiveness of reflective journals as a tool to reflect on the teaching practices of developing students as well. [34]. In other words, besides reflect personal, social, and ethical issues in journals, students need to focus on specific problems in class and systematically document their practical experiences [35]. Students will feel the importance of reflective journals in advancing their learning if teachers and students are consistently using reflective journals to reflect on learning. If used consistently, this reflective journal will greatly help students to develop their metacognitive awareness [9], the metacognitive strategy [36]. Metacognitive awareness of students will increase if writing a reflective journal becomes a weekly routine to achieve learning goals [10]. Journals that are collected as a routine every week can be given by teachers through online media, such as blogs [37]. Providing journals online is more effective than traditional methods [38]. Online journals via blogs and emails can facilitate the expression of their thoughts, learn and share knowledge with each other, and increase their understanding of the concepts they learn [38].

The students of metacognition growth will be seen and recorded in reflective journals. They will gradually form an awareness of cognition, tasks, and themselves. They also monitor the cognitive process through the process of evaluating the progress of learning outcomes. If this process is carried out consistently it will form habits in learning, which is to control and control the learning process itself. This is what is meant by the metacognition process, starting from awareness, evaluation, and regulation.

Metacognitive awareness shows the process of using reflective thinking to develop awareness about himself, his tasks, and his own knowledge strategies in a particular context. This metacognitive awareness has a great influence on self-control and the achievement of goals, this is what is called metacognitive beliefs [39]. Metacognitive beliefs will guide students to have self-efficacy on their own learning goals so that they can develop positive expectations on their performance and reward hard work as the key to their success [40]. Students who have metacognitive beliefs will be able to control their own learning and will become independent learners.

Assessment and monitoring of metacognition is a reflection of actions in the form of task assessment activities, assessment of understanding, and assessment of the 
development of the learning process. Reflection on actions also means awareness and willingness to reflect on the learning process [24]. Assessment and monitoring of metacognition can be divided into four types, namely: monitoring task difficulties and ease of learning assessment, monitoring understanding and assessment of learning, monitoring feeling of knowing, and monitoring the progress of learning outcomes [23]. Assessment of the progress of learning outcomes, for example in writing, can be done by students by assessing according to established criteria or comparing their own writing with the writings of others through the focus group discussion. During this process, the teacher can encourage students to reflect on how to carry out language assignments by finding alternatives for less effective strategies as a form of evaluation of the strategies used, the teacher not only provides comments on the accuracy of writing but also on the strategies used by students. The things that are done by the teacher can help students have the confidence to learn languages [41] [42]. When students reflect on their learning strategies, they become better prepared to make conscious decisions about what they can do to improve their learning [43].

Self-regulation and control is a reflection in action in the form of efforts to control and control the learning process to achieve meaningful learning outcomes. Self-regulation and control are divided into four types, namely: planning activities; setting goals for learning; use time; and performance, strategy selection and decision making efforts about the strategy used for a task or when to change the strategy when performing a task, allocation of control of resources and regulation of the use of time; effort; learning steps and efforts, and control and regulation of motivation; emotion; and the environment [23]. Self-regulation and control are also closely related to the provision of control in the form of certain metacognitive strategies to students. Self-regulation and control are carried out through collaborative processes by conditioning internal and external factors and are assessed continuously. Learners can engage in learning by asking for help from others reciprocally to improve the learning experience and realize the desired results [24].

All metacognition activities ranging from awareness, evaluation, and regulation will be recorded in the student's reflective journal. So that the use of reflective journals in the writing process can be carried out effectively, the teacher's role is very necessary. The teacher's role is to provide feedback on journals written by students so that they find their own weaknesses and strengths and challenge their writing techniques [6]. The teacher must also be able to convince students that journal writing is a useful tool for learning about teaching and for demonstrating its effectiveness as a way to structure future actions and assess their own learning [21]. Teachers who are accustomed to giving feedback on the results of students 'reflections will have an influence on improving students' motivation, process, and performance [44].

In order for students to be able to convey everything that was thought during the reflection process, the teacher must be able to distinguish between formal assessments and reflection evaluations, both of which are two different things [1]. To get grades, students will give and display their best work. They will tend to demonstrate what they know and disguise what they don't know. In contrast to reflection, students are required to express their doubts, express their lack of understanding, and focus on things they do not know. Assessment sometimes inhibits students to convey what they think because 
he will continue to think who will read the journal [45]. To address this, the teacher must be able to judge the journal without being judgmental. He must respect the writing, maintain the confidentiality of the writing, and try to understand, involve, and express honest and innovative responses [46]. Teachers need to respect students' writing because the reality of writing in perfect language is the greatest fear of beginner writers and proficient writers from time to time [47].

In an effort to analyze the reflection process, there are three main components that need to be the attention of teachers and students, namely goals driven by the ego, restructuring abilities, and transformation perspectives [48]. In this effort, as the party who will respond to the students 'journals, the teacher must build responsive relationships with students by emphasizing and motivating journal writing, helping students see more in writing what they have missed or ignored, and entering into students' conversations by investigating, expanding, and connecting [46]. Thus, reflective journals will be able to function as a means of communication between teachers and students and promote a narrative approach to research and teaching. Reflection journals in this context, not only document learning but also enhance and stimulate learning [49].

\section{Conclusion}

Writing reflective journals becomes a reflection technique in the learning process that provides a variety of benefits for students. Through reflective journals, students can enhance their learning experience. Students can reflect on everything done during the process. Reflective journals can play a role in growing student metacognition in writing. By integrating the metacognition process into the reflective journal guide, it indirectly helps students to grow and awakens their metacognition during the completion of the task. The metacognition process consisting of awareness, evaluation, and regulation will be seen during the writing process because all three aspects are presented in the form of self-questioning. The awareness process will occur when students are dealing with assignments. He began to think about knowledge and task completion efforts. The evaluation process will be seen when students begin to critically consider the knowledge they have and the quality of the results obtained. The regulation process is seen when students rethink planning, goals, and strategies that can be used. The regulation process is the highest process that forms the habits in learners to always plan, set goals, and implement certain strategies in completing tasks. Students who are able to go through these three processes in the process of completing the task can be said that they have been able to realize and utilize their metacognition well. They will grow into independent learners. The intended independent learners are students who are able to complete their own tasks with or without help from others, are able to realize the benefits of the strategies used, are able to assess their own understanding when receiving or using various information received in an effort to complete a task, and have the habit to plan, set goals, and implement certain strategies in completing tasks. 


\section{Acknowledgement}

This article is part of the results of research being carried out entitled "The Construction of Students' Metacognition in Writing". This research was funded by PNBP Universitas Negeri Malang (UM) in 2020. Acknowledgments The authors convey to Prof. Dr. Anang Santoso, M.Pd. from Fakultas Sastra, Universitas Negeri Malang, who has been willing to validate the reflective journal guidelines and provide suggestions for improvement for the perfection of the reflective journal guidelines so that it can be used to monitor the students' of metacognition growth in doing writing assignments. Students of the Program Studi Pendidikan Bahasa dan Sastra Indonesia, STKIP PGRI Sumatera Barat, Indonesia as subjects of small group trials and field trials. The Head of STKIP PGRI Sumatera Barat, Indonesia who has given permission to carry out research. The editorial team of the International Journal of Emerging Technologies in Learning (iJET) has agreed to review and publish this article.

\section{$7 \quad$ References}

[1] D. Boud, "Using Journal Writing to Enhance Reflective Practice," in Promoting Journal Writing in Adult Education, L. M. English and M. A. Gillen, Eds. San Francisco: JosseyBass Summer, 2001, pp. 9-18.

[2] L. Mcguire, K. Lay, and J. Peters, "Pedagogy of Reflective Writing in Professional Education," J. Scholarsh. Teach. Learn., vol. 9, no. 1, pp. 93-107, 2009.

[3] A. Liuolienè and R. Metiūnienè, "Students' Learning through Reflection Journaling," Santalka Filol. Edukogija, vol. 17, no. 4, pp. 32-37, 2009. https://doi.org/10.3846/1822430x.2009.17.4.32-37

[4] R. Hiemstra, "Uses and Benefits of Journal Writing," in Promoting Journal Writing in Adult Education, L. M. English and M. A. Gillen, Eds. San Francisco: Jossey-Bass Summer, 2001, pp. 19-26.

[5] B. Xhaferi and G. Xhaferi, "Enhancing Learning Through Reflection - A Case Study of SEEU,” SEEU Rev., pp. 53-68, 2017. https://doi.org/10.1515/seeur-2017-0004

[6] Z. Hashemi and T. Mirzaei, "Conversations of the Mind: The Impact of Journal Writing on Enhancing EFL Medical Students' Reflections, Attitudes, and Sense of Self," Procedia Soc. Behav. Sci., vol. 199, pp. 103-110, 2015. https://doi.org/10.1016/j.sbspro.2015.07. $\underline{493}$

[7] R. A. Orem, "Journal Writing in Adult ESL: Improving Practice Through Reflective Writing," in Promoting Journal Writing in Adult Education, L. M. English and M. A. Gillen, Eds. San Francisco: Jossey-Bass Summer, 2001, pp. 69-78. https://doi.org/10.1002/ace.22

[8] C. Tang, "Reflective Diaries as a Means of Facilitating and Assessing Reflection," in Paper presented at the Proceedings of the 2002 Annual International Conference of the Higher Education Research and Development Society of Australasia (HERDSA) Perth, Australia, 2002.

[9] C. C. Swanson, “Journal Writing: A Metacognitive Strategy,” J. Coll. Read. Learn., vol. 17, no. 1, pp. 185-191, 1984.

[10] R. Henter and E. S. Indreica, "Reflective Journal Writing as a Metacognitive Tool," in International Conference of Scientific Paper, 2016, no. May 2014.

[11] B. A. Sen, "Reflective Writing: A Management Skill," Libr. Manag., vol. 31, no. 1/2, pp. 79-93, 2010. 
[12] T. O'Connell and J. Dyment, "Reflection on Using Journal in Higher Education: A Focus Group Discussion with Faculty," Assess. Eval. High. Educ., vol. 31, no. 6, pp. 671--691, 2006.

[13] F. Habibi, I. Eviyuliwati, and S. Kartowisastro, "The Effect of Reflective Journal Writing on Students' Writing Ability of Narrative Text," in Advances in Social Science, Education and Humanities Research., 2018, vol. 115, no. International Conferences on Education in Muslim 2017, pp. 16-20. https://doi.org/10.2991/icems-17.2018.4

[14] P. D. Klein and P. Boscolo, "Trends in Research on Writing as a Learning Activity,” J. Writ. Res., vol. 7, no. 3, pp. 311-350, 2016.

[15] Y. Apsari, "Reflective Reading Journal in Teaching Writing," Indones. EFL J., vol. 4, no. 2, pp. 39-47, 2018.

[16] S. Lee, "Effects of Reflective Journal Writing in Japanese Students' Language Learning," Indiana University of Pennsylvania, 2013.

[17] N. M. Al-Rawahi and S. M. Al-Balushi, "The Effect of Reflective Science Journal Writing on Students' Self-Regulated Learning Strategies," Int. J. Environ. Sci. Educ., vol. 10, no. 3, pp. 367-379, 2015.

[18] D. Ramadhanti, A. S. Ghazali, M. Hasanah and T. Harsiati, "Students' Metacognitive Weaknesses in Academic Writing: A Preliminary Research,” Int. J. Emerg. Technol. Learn., vol. 14, no. 11, pp. 41-57, 2019. https://doi.org/10.3991/ijet.v14i11.10213

[19] M. A. A. Farrah, "Reflective Journal Writing as an Effective Technique in the Writing Process," An-Najah Univ. J. Res, vol. 26, no. 4, pp. 997-1025, 2012.

[20] F. F. Estrada, H. Mariam, and A. Rahman, "Reflective Journal Writing as an Approach to Enhancing Students' Learning Experience,” Brunai Darussalam, vol. 8, no. 1, pp. 22-35, 2014.

[21] G. C. Evans and C. Maloney, "An Analysis Framework for Reflective Writ-ing," Aust. J. Teach. Educ., vol. 23, no. 1, pp. 29-39, 1998.

[22] M. T. Magiera and J. S. Zawojweski, "Characterizations of Social-Based and Self-Based Contexts Associated with Students' Awareness, Evaluation, and Regulation of Their Thinking During Small-Group Mathematical Modeling,” J. Res. Math. Educ., vol. 42, no. 5, pp. 486-520, 2011. https://doi.org/10.5951/jresematheduc.42.5.0486

[23] P. R. Pintrich, C. A. Wolters, and G. P. Baxter, "Assessing Metacognition and Self-Regulated Learning," in Issue in the Measurement of Metacognition, G. Schraw, and J. C. Impara, Eds. NE: University of Nebraska-Lincoln, 2000, pp. 43-97.

[24] Z. Akyol and D. R. Garrison, “Assessing Metacognitive in an Online of Inquiry," Internet High. Educ., vol. 14, no. 3, pp. 183-190, 2011.

[25] D. R. Garrison and Z. Akyol, "Toward the Development of a Metacognition Construct for Communities of Inquiry,” Internet High. Educ., vol. 24, no. 4, pp. 66-71, 2015. https://doi. org/10.1016/j.iheduc.2014.10.001

[26] Z. Hu and Z. Deng, "The Construct of Metacognition in the Processing of Translation Problems and its Measurement,” Top. Educ. Cult. Soc. Dev., vol. 1, no. 1, pp. 76-78, 2018.

[27] K. R. Haris, T. Santangelo, and S. Graham, "Metacognition and Strategies Instruction in Writing," in Metacognition, Strategies Use, \& Instruction, H. S. Waters and W. Schneider, Eds. London: The Guilford Press, 2010, pp. 226--256.

[28] H. J. Hartman, "Developing Students' Metacognitive Knowledge and Skill," in Metacognition in Learning and Instruction: Theory, Research, and Practice, H. J. Hartman, Ed. New York: Springer, 2002, pp. 33-68. https://doi.org/10.1007/978-94-017-2243-8_3

[29] D. Ramadhanti, D. P. Yanda, A. S. Ghazali, M. Hasanah and T. Harsiati, "Development of Explanatory Text Writing Evaluation Tools Based on a Process Approach (Pengembangan Alat Evaluasi Menulis Teks Eksplanasi Berbasis Pendekatan Proses)," J. Gramatika J. 
Penelit. Pendidik. Bhs. dan Sastra Indones., vol. 5, no. 2, pp. 194-210, 2019. https://doi.org/10.22202/jg.2019.v5i2.3445

[30] L. Flower and J. R. Hayes, "A Cognitive Process Theory of Writing," Coll. Compos. Commun., vol. 32, no. 4, p. 365, 1981.

[31] M. Anderson and K. Anderson, Text Types in English 1. South Yarra: Mac-Millan Education Australia, 1997.

[32] P. Wallin, T. Adawi, and J. Gold, "Reflective Diaries - A Tool for Promoting and Probing Student Learning," in Proceeding of the 12th International CDIO Conferences, 2016.

[33] P. Jarvis, "Journal Writing in Higher Education," in Promoting Journal Writing in Adult Education, L. M. English and M. A. Gillen, Eds. San Francisco: Jossey-Bass Summer, 2001, pp. 79-86.

[34] R. M. Melendez, M. B. Garza, E. A. Vazquez, and G. Q. Zavala, "Reflective Journal: The Learners' Perspective in Formal Instruction,” Eur. Sci. J., vol. 15, no. 10, pp. 252-260, 2019. https://doi.org/10.19044/esj.2019.v15n10p252

[35] T. Zuckermann and M. Rajuan, "From Journal Writing to Action Research: Steps Toward Systematic Reflective Writing," 2008.

[36] O. Clipa, A. A. Ignat, and M. Stanciu, "Learning Diary as a Tool for Meta-cognitive Strategies Development," Procedia - Soc. Behav. Sci., vol. 33, pp. 905-909, 2012. https://doi. org/10.1016/j.sbspro.2012.01.253

[37] A. Z. Mansor, "Reflective Learning Journal Using Blog," Procedia - Soc. Behav. Sci., vol. 18, pp. 507-516, 2011.

[38] D. S. Kaplan, W. H. Rupley, J. Sparks, and A. Holcomb, "Comparing Traditional Journal Writing with Journal Writing Shared over E-mail List Serves as Tools for Facilitating Reflective Thinking: A Study of Preservice Teachers," J. Lit. Res., vol. 39, no. 3, pp. 357-387, 2007. https://doi.org/10.1080/10862960701613136

[39] D. S. Ridley, P. A. Schutz, and R. S. Glanz, "Self-Regulated Learning: The Interactive Influence of Metacognitive Awareness and Goal-Setting," J. Exp. Educ., vol. 60, no. 4, pp. 293-306, 1992. https://doi.org/10.1080/00220973.1992.9943867

[40] J. Wang, K. Spencer, and M. Xing, "Metacognitive Beliefs and Strategies in Learning Chinese as a Foreign Language," System, vol. 37, no. 1, pp. 46-56, 2009. https://doi.org/10. 1016/j.system.2008.05.001

[41] S. J. Graham, "Learners' Metacognitive beliefs: A Modern Foreign Languages case study," Res. Educ., no. 70, pp. 9-20, 2002.

[42] Wenden, "Metacognitive Knowledge and Language learning," Appl. Linguist., vol. 19, no. 4, pp. 515-537, 1998.

[43] N. J. Anderson, "The Role of Metacognition in Second Language Teaching and Learning," ERIC Dig., vol. 1, no. 10, pp. 2-5, 2002.

[44] H. Duijnhouwer, F. J. Prins, and K. M. Stokking, "Feedback Providing Improvement Strategies and Reflection on Feedback Use: Effects on Students' Writing Motivation, Process, and Performance," Learn. Instr., vol. 22, pp. 171-184, 2012. https://doi.org/10.1016/j. learninstruc.2011.10.003

[45] L. M. English, "Ethical Concerns Relating to Journal Writing," in Promoting Journal Writing in Adult Education, L. M. English and M. A. Gillen, Eds. San Fran-cisco: Jossey-Bass Summer, 2001, pp. 27-36.

[46] T. J. Fenwick, "Responding to Journal in a Learning Process," in Promoting Journal Writing in Adult Education, L. M. English and M. A. Gillen, Eds. San Fran-cisco: Jossey-Bass Summer, 2001, pp. 37-48. 
[47] L. M. English and M. A. Gillen, "Journal Writing in Practice: From Vision to Reality," in Promoting Journal Writing in Adult Education, L. M. English and M. A. Gillen, Eds. San Francisco: Jossey-Bass Summer, 2001, pp. 87-95. https://doi.org/10.1002/ace.24

[48] P. Silcock, "The Process of Reflective Teaching," Br. J. Educ. Stud., vol. 42, no. 3, pp. 273285, 1994.

[49] R. Phelps, "The Potential of Reflective Journals in Studying Complexity in Action," Complicity an Int. J. Complex. Education, vol. 2, no. 1, pp. 37-54, 2005. https://doi.org/10. 29173/cmplct8726

\section{Authors}

Dina Ramadhanti is a doctoral student at the Postgraduate Universitas Negeri Malang, Indonesia and a lecturer at STKIP PGRI Sumatera Barat, Indonesia. Email: dina_ramadhanti89@yahoo.com. (Scopus Id: 57210338983)

A. Syukur Ghazali (corresponding author) is an expert and professor of psycholinguistics who teaches at Fakultas Sastra and Pascasarjana of Universitas Negeri Malang, Indonesia. Email: syukurghazali.fsum@gmail.com (Scopus Id: 57209732614)

Muakibatul Hasanah is an expert in the field of teaching Indonesian language and literature at Fakultas Sastra and Pascasarjana of Universitas Negeri Malang, Indonesia. Email: akibba.fs@um.ac.id (Scopus Id: 57210346043)

Titik Harsiati is an expert in the field of evaluation of learning Indonesian language and literature at Fakultas Sastra and Pascasarjana of Universitas Negeri Malang, Indonesia. Email: titik.harsiati.fs@um.ac.id (Scopus Id: 57210259088)

Diyan Permata Yanda is a lecturer and researcher at STKIP PGRI Sumatera Barat, Indonesia. Email: diyan_yanda@yahoo.com. (Scopus Id: 57204847116)

Article submitted 2019-10-21. Resubmitted 2020-03-07. Final acceptance 2020-03-08. Final version published as submitted by the authors. 


\section{APPENDIX 1}

\subsection{Reflective journal guidelines in writing}

\section{Instruction}

Explain the method or strategy you used in writing the explanatory text by selecting one or more statements that fit your experience!

You can provide other explanations according to your experience before, during, and after writing explanatory text if it has not been listed in the choice of a statement given! Give further explanation or a more detailed example of your experience in writing explanatory texts, if you choose alternative answers that are starred $(*)$

Answer each question honestly because this journal serves to monitor your level of success in writing explanatory texts!

\subsection{List of reflective journal questions}

1. I realize the goal that I want to achieve in writing explanatory texts, because:

a) Through this topic, I can explain the knowledge and experience I have to the reader. * (*explain more about what knowledge and experience you have on the topic!)

b) Through this topic, I can provide an explanation of a phenomenon so that the reader has a certain view of the phenomenon that I describe. * (*explain more about what kind of views you expect from readers after reading your writing!)

c) Through this topic, I can explain various problems that I often find in my daily environment. * (*mention examples of problems you encounter in your daily environment according to the topic!)

d) I have almost the same experience as the topic I chose. * (*describe what experience you have on the topic!)

2. I'm aware of the topic that I will write in the form of explanatory text, because:

a) I often read information about problems that fit the topic in online media, especially online media. *(*Mention examples of what information you read about the topic on social media!)

b) I have an interest in a topic because I have almost the same experience with that topic. * (*Mention what experience you have on the topic!)

c) I once read an article about that topic. * (*Explain the contents of that article!)

d) For me, the topic I chose is part of a social phenomenon that has become part of people's lives today. * (*xplain why this is so!)

3. I realize the needs of the audience in writing this topic in the form of explanatory text. Therefore:

a) I write this topic for anyone because indeed problems like this are often encountered in my daily environment. * (*Mention an example of the problem!) 
b) I wrote this topic for myself so that I could avoid despicable behavior.

c) I write this topic for teenagers who are accustomed to using social media and always a reason not to have enough time to study.

d) I wrote this topic for my friends because they have similar characteristics to this topic. * (*Mention an example of what kind of character you mean!)

4. I'm aware of the scope that I will write, because:

a) I have identified the problems that I will write on the topic, for example: what is the problem, who is experiencing the problem, what are the examples, when it must be resolved, what makes it a problem, why should it be solved, and why it is the best solution to solve the problem.* (*Mention what problems you have identified to answer the question briefly!)

b) I have conducted observations, surveys, and interviews to find data and facts as written material. * (*Mention when, where and what you observed, what you surveyed, who you interviewed and what your interview contained!)

c) I have formulated a topic and recognized the reasons for choosing a topic by paying attention to the target/reader. * *Mention state the reason for choosing the topic you are referring to!)

d) I collect written material from various sources, both books, journals, and expert opinions to support the information I explain. * (*Mention examples of each material that you collect, discuss what materials you find it!)

5. I'm aware of the genre of the text I will write, especially the explanatory text genre, i.e:

a) I know that the presentation of the title in the explanatory text is usually in the form of a question sentence. * (*Mention the example in the text of the explanation text you wrote and why!)

b) I know that the general statement in the introduction to the explanatory text must contain the presentation of the problem as an initial description for the reader about the topic.* (*Mention the example in the text of the explanatory text you are writing and the way you are doing to present the introduction to the explanatory text!)

c) I know that the information presented in the body part or the contents of the explanatory text is in the form of an explanation of why and how the problem being discussed, can be in the form of similarities and differences in a matter, it can also be an effort to solve a problem in a matter.* (*Mention the example in writing the explanatory text that you wrote and what you did to present the contents of the explanatory text!)

d) I know that the conclusions in the concluding section of the explanatory text can be in the form of predictions or a combination of information that has been selected or combined as indicated in the contents of the text.* (*Mention the example in the text of the explanatory text you are writing and how you do it to present the conclusions of the explanatory text!)

6. I'm aware of the linguistic structure that I need to pay attention to in writing explanatory texts, for example: 
a) I know about how to use technical terms according to specific fields of study in explanatory text writing. * (*Mention examples of technical terms that you use in your explanatory text and why you chose those terms!)

b) I know the markers of causality to connect some information in the explanatory text. * (*Mention the markers of causality that you use along with examples in your explanatory writing, and why you chose the linguistic marker!)

c) I know the time sequence relation markers in the explanatory text. * (*Mention the time sequence relation markers you used along with examples in your explanatory texts, and why you chose the linguistic marker!)

d) I know the markers of comparative and conflicting relationships to explain the similarities and differences of things in explanatory texts. * (*Mention the markers of the comparison and conflict that you are using along with examples in your explanatory writing, and why you chose the linguistic marker!)

7. I realize the process of writing explanatory texts, that is by way of .

a) I plan my writing well. * (*xplain the things you did when you planned the writing and why you chose it that way!)

b) I'm revising the explanatory text that I have written to check the completeness and adequacy of the information I present. * (*Explain what you are doing in revising the explanatory text!)

c) I developed the idea according to the information I got while planning the writing. * (*Explain the things you did while developing the idea and why you chose it that way!)

d) I formulated the title according to the topic I wrote in the explanatory text.* (*Explain why you chose that title!)

8. I realized the way I had done while planning the explanatory text writing, that is by way of:

a) I read the writing material on the topic, study every idea, underline every important idea, and copy the parts of the writing. * (*Mention what writing material you are reading!)

b) I made the writing framework in the form of mind mapping to help me develop my ideas according to the topic. * (*Exlain the things you did in making mind mapping and what sources you used to make the mind mapping!)

c) I observe, summarize, take notes, and formulate questions according to the topic I will write. * (*Mention what you observe, what you summarize, record, and questions that you formulate about the topic!)

d) I set my goals for writing this topic and whose goals it is, then estimate enough time and resources to finish writing. * (*Mention your goals and objectives and how much time you need to complete your explanatory text!)

9. I realized the way that I did while producing the text, especially in choosing the vocabulary that I used, that is by way of: 
a) I record and list the vocabulary that I know about the topic and find out what vocabulary I need to develop the topic. * (*Mention examples of vocabulary that you know and find and then develop in your explanatory text!)

b) I write whatever vocabulary I think of when writing topics and add less vocabulary by reading written material. * (*Explain the example of the vocabulary that you developed in your explanatory text!)

c) I know the vocabulary of various word classes because I am diligent in reading so that I easily develop ideas according to the vocabulary that I have. * (*Mention examples of vocabulary from various classes of words that you know!)

d) I choose the vocabulary that fits the topic, then I describe it in the form of a semantic network map. The vocabulary that I described was connected to a semantic network map. * (*Describe the shape of the semantic network map and how you get interconnected vocabulary for you to present in the semantic network map!)

10. I realize the way that I do while producing text, especially in arranging sentences according to their structure and function so that the sentences and sentence patterns that I present are more varied. The way I do that is:

a) I always pay attention to the syntactic structure in writing, at least my sentences are patterned S, P. For me simple sentences can also be complex sentences if I use conjunctions between sentences. * (*Mention the example in the explanatory text that you write!)

b) I choose the vocabulary of certain word classes according to their function in the sentence, for example, the subject of the noun word class and the predicate of the verb word class and then I arrange them according to their function in the sentence so that they form sentences with varying patterns and shapes.* (*Mention the example of the sentence structuring in your explanatory text and how many patterns or variations of the sentence you present in the explanatory text!)

c) I wrote down everything I thought about the topic. After is complete, I double-check the accuracy of my writing in terms of syntactic rules. * (*Mention an example in your explanatory text!)

d) I studied syntactic rules first because I lacked mastery of syntactic subjects which resulted in my writing being ineffective.* (*Mention an example in your explanatory text, then explain how you did this to make the explanatory text you write more effective and communicative!)

11. I'm aware of the way I have done while producing text, especially in the selection of lexical and grammatical cohesion in connecting each part of the sentence to a coherent paragraph, that is by way of:

a) I chose appropriate conjunction to connect simple sentences to complex sentences or to connect single sentences into compound sentences. * (*Mention examples of using conjunctions in the explanatory text you write!)

b) I chose certain linguistic relationship markers, for example, time or sequence relationships to link information that contains a specific stage or chronology of time.* 
(*Mention examples of the use of time or sequence relationships in the explanatory text you write!)

c) I chose a marker of cause-effect relationships because the explanatory text discusses the attempt to solve a problem and must be able to answer the question of why and why a problem occurs and how to solve the problem.* (*Mention examples of the use of such relationship markers in the explanatory text that you write!)

d) I chose a marker of comparative and conflicting relations because of the explanatory text I wrote contains strengths and weaknesses about something. * (*Mention an example in the explanatory text you wrote!)

12. I realized the way that I had done while developing ideas in the form of explanatory texts, that is by way of:

a) I choose the appropriate vocabulary, arrange it according to its function in the sentence, and arrange each idea using the appropriate conjunctions. * (*Mention one example from the text section of your explanatory text and why you are using it!)

b) I compare various interrelated issues, classify them, sort them, and present them appropriately in the form of a coherent set of paragraphs. * (*Mention one example from the text section of your explanatory text and why you are using it!)

c) I relate each item of information I get about the topic, such as research results, expert opinions, or important quotes and add them to my writing. * (*Mention one example from the text section of your explanatory text and why you use it!)

d) I pay attention to every component in my writing, identify the relationship between sentences, pay attention to the relationship between the main idea and explanatory ideas and try not to do errors in writing.* (*Mention one example of each from the text section of your explanatory text and why you are using this method!)

13. I realize the way that I do to connect ideas in writing explanatory texts, that is by way of:

a) I write with attention to the relationship between the main idea and the explanatory idea. Every paragraph I write consists of a main idea and some explanatory ideas. * (*Mention one example from the text section of your explanatory text and why you are using it!)

b) I use a causal relationship marker to connect ideas in the form of reasons and evidence to support the information I write, for example from research results, expert opinions, or important quotes.* (*Mention one example from the text section of your explanatory text and why you are using this method!)

c) I use conjunctions to connect every idea in my writing. * (*Mention one example from the text section of your explanatory text and why you use it!)

d) I link ideas by extracting some expert opinions and research results supported by the use of linguistic relationship markers according to the information I present. * (*Mention one example from the text section of your explanatory text and why you are using it!)

14. I realized the way that I did to add detail to my writing, that is by way of: 
a) I associate one information with another using a causal marker or using an analogy or parable. * (*Mention one example from the text section of your explanatory text and why you are using it!)

b) I compare some information that fits the topic and classify ideas that fit the topic, then add it to the text. * (*Mention one example from the text section of your explanatory text and why you are using it!)

c) I add factual information to clarify the topic I wrote using a place marker, time, or expert opinion. * (*Mention one example from the text section of your explanatory text and why you are using it!)

d) I sort every item of information I get and present it coherently in my writing. * (*Mention one example from the text section of your explanatory text and why you are using it!)

15. I realized the way I did while revising the text, that is by way of:

a) I identify every concept that I present in the text and examine the relationship of each part, whether it has been coherent or not. If mistakes are still found, then I correct it. * (*Mention the example of the text portion of your explanatory text that you corrected and why that part was repaired!)

b) I checked the completeness and accuracy of the structure of the text and the ruleslanguage of the text. If I find an error, I correct it. * (*Mention the example of the text section of your explanatory text that you corrected and why that part was repaired!)

c) I examine each paragraph, whether it has several explanatory ideas to support the main idea. If an error is found, I will correct it right away. * (*Mention the example of the text section of your explanatory text that you corrected and why that part was repaired!)

d) I check the proper use of conjunctions, for example, markers of cause-effect relationships to link any information; use of technical languages in accordance with certain fields of science; or markers of comparative or conflicting relationships if I explain the similarities or differences of things.* (*Mention an example of the text portion of your explanatory text that you corrected and why that part you repaired!)

16. I considered critically about the task of writing explanatory texts, because:

a) The topic I wrote is very interesting and useful to me. * (*Mention the benefits of the topic you choose for you!)

b) I like writing and I don't want to make mistakes in writing.

c) This topic is in accordance with the issues that are currently being discussed in society. * (*Mention an example!)

d) I feel that by writing I can express all my thoughts about various phenomena. * (*Mention examples of that phenomena!)

17. I determine the best skills and strategies that I can use in writing explanatory texts, for example: 
a) Before I write, I plan my writing, look for and read written material and develop it into written ideas. * (*Mention one of the examples from the text section of your explanatory text and why you call it your best writing strategy!)

b) I made a mind map to map out every concept I would develop into writing. * (*Explain why you call it your best writing strategy!)

c) I read a lot. Without reading I will not be able to write because for me good writing comes from the amount of knowledge gained through reading. * (*Mention one example from the text section of your explanatory text and why you call it your best writing strategy!)

d) I'm used to writing whatever I think and feel because for me writing has become a part of my life. * (*xplain why this is so!)

18. I determine the type of scaffolding that can help me in completing the task of writing explanatory text, for example:

a) I have discussions with peers and anyone in my daily environment to help me get the information I need. * (*Explain why you chose this way!)

b) I read a lot of books or watch videos about specific cases to help me find ideas in writing. * (*Mention the book you read and sample video case, explain the idea as to what you find from both of them!)

c) I need examples of writing, for example, explanatory texts in order to understand the text and I can practice writing these types of texts. * (*Mention examples of explanatory texts that you have ever read!)

d) I conduct investigations in the daily environment to add to my writing material. * (*xplain the investigation as to what you did and why carry out the investigation!)

19. I can identify when and why I use certain writing processes to produce explanatory texts, because:

a) I have many ways and strategies that I can use in writing. * (*Explain the method and strategy that you use in writing explanatory text!)

b) I have certain habits from my childhood that can influence the strategies I use in writing. * (*xplain what habits you mean!)

c) I must use the right strategy in writing so that the writing I produce is more communicative and meets the criteria of the text. * (*xplain what strategy it is!)

d) I have good critical thinking and problem-solving skills. * (*xplain one piece of evidence that shows that you are a creative thinker and a good problem solver of the explanatory text that you write!)

20. I always modify my learning environment in writing explanatory texts, because:

a) I feel that a comfortable environment is an important key in writing. * (*Explain what kind of environment you mean!)

b) I cannot learn if the environment that I meet does not vary. * $(*$ Mention examples of that varied environments!)

c) I'm an introvert and need peace and comfort to study, especially writing. 
d) I like new things and a new atmosphere for learning. * (*Mention examples of those new things and new atmosphere!)

21. I know the nature of the task of writing this explanatory text according to the knowledge and experience I have. Therefore:

a) I find it easy to complete this task. * (*Mention what kind of convenience you mean!)

b) I need to share that knowledge and experience with peers in the way I discuss it with them in order to complete this task. * (*Mention what is your knowledge and experience!)

c) I don't need a long time to complete this task. * (*Mention how long you need to write explanatory text!)

d) I need to find the resources I need to further enrich the knowledge and experience I have. * (*Mention examples of sources that can enrich your knowledge and experience!)

22. I connect the knowledge and experience I have in accordance with the task of writing explanatory texts, that is by way of:

a) I recall the things that I have experienced and encountered and write them down supported by reason and evidence that make sense. * (*Mention the things you remember about the topic!)

b) I connect the knowledge and experience I have with the topic and add to it with more recent information. * (*Mention an example from the text section of your explanation!)

c) I use that knowledge and experience as my strength in writing. * (*Mention what kind of knowledge and experience you mean!)

d) I wrote down all of that knowledge and experience and adapted it to the topic of the writing. * (*Mention one example from the part of your writing!)

23. My weakness in writing explanatory texts is:

a) I find it very difficult to concentrate on writing and often experience obstacles in writing, both internal and external obstacles. * (*Mention the obstacles and why they are obstacles to your writing!)

b) I have difficulty presenting effective writing. I tend to write the language I speak so that the sentence I produce is ineffective. * (*Mention an example of writing your explanatory text!)

c) I am not a good thinker so the writing I produce is too ordinary and has no appeal. * (*Mention an example in your writing and what you do to make your writing more communicative according to the explanatory text criteria!)

d) I tend to be unaware of the factors that can help and hinder my writing. (*Explain the impact of this on your writing!)

24. My strengths in writing explanatory texts is:

a) I have critical thinking skills so that I find it easy to connect every idea in writing. * (*Mention an example from the text section of your explanatory text!) 
b) I have such a high level of accuracy that no errors were found in my writing in terms of both the structure and the language norms of the text. * (*Mention an example from the text section of your explanatory text!)

c) I'm very skilled at solving problems so the explanatory text that I write is predictive of the results of the problem-solving effort according to the topic. * (*Mention an example from the text section of your explanatory text!)

d) I know several factors that can help me improve my thinking in writing and the things that can motivate me to write. * (*Mention what factors are and why!)

25. I understand how difficult the task of writing explanatory texts. Therefore:

a) I often understand examples of explanatory texts and often practice writing. * (*Mention examples of that texts!)

b) I read a lot to add knowledge and ideas in writing. * (*Mention what you read to increase knowledge in writing!)

c) I often ask questions and discuss with peers. * (*Mention what things you ask and discuss!)

d) I often read books on writing tips and make a list of my difficulties in writing and try to improve them. * (*Mention the book you read and the impact of the assessment you made on your writing!)

26. I understand every aspect of the judgment that must be considered while writing explanatory texts. Therefore:

a) I must be able to produce an explanatory text with the correct structure and rules of language.

b) I'm constantly aware of every effort I make in writing. * (*Mention the efforts you made!)

c) I must be able to present an introductory part that can attract the attention of the reader, a series of information using a causal relationship marker, and a concluding section that shows conclusions from the information that I present.

d) I need to write correctly and monitor the progress of my writing using the assessment rubrics provided so that my writing matches the explanatory text criteria. * (*Explain how your writing has progressed after being assessed using that rubric!)

27. I always monitor my understanding while writing explanatory texts, that is by way of:

a) I pay attention to the structural accuracy and linguistic rules of the text.

b) I'm revising the text I have written. * (*Mention which part revising!)

c) I read my writing over and over again and make revisions if mistakes are still found.

d) I ask the help of peers to read my writing. * (*Mention your friend's response and what advice is given in connection with your writing!)

28. I made an assessment of the explanatory text that I wrote, that is by way of:

a) I do my own assessment according to the assessment rubric. * (*Explain how your assessment results!) 
b) I and peers give each other assessments and provide input to improve writing. * (*Mention your response in connection with your writing!)

c) I ask the help of peers to check my writing. * (*Mention your friend's response to your writing!)

d) I do my own assessment using the assessment rubric that I developed myself. * (*Explain how your results will be!)

29. I monitor a level of awareness of knowledge and experience that is difficult to remember in connection with the task of writing explanatory texts, that is by way of:

a) I'm constantly aware of every effort I make during the writing process. * (*Explain what effort you consciously did!)

b) I continued to monitor my feelings during the writing process. * (*Explain how you felt while working on the task of writing explanatory texts!)

c) I'm aware of the level of my thinking while completing writing assignments. * (*Explain how your level of thinking is in completing writing explanatory text assignments!)

d) I monitor every process that I do while writing. * (*Explain how you monitor the process that you do when writing explanatory text!)

30. I make and check the progress of writing explanatory text according to the evaluation criteria of writing explanatory text, that is by way of:

a) I consciously assessed my understanding during the writing process. * (*Mention examples of what you understood during the writing process!)

b) I keep trying to approach and do the writing assignments. * (*Mention what kind of effort you mean!)

c) I heeded the advice of peers to improve my writing. * (*Mention what advice your friend gave!)

d) I'm assessing and revising my writing to fit the criteria. * (*Mention which part of your writing you are revising!)

31. I have a habit of planning assignments and the purpose of writing assignments as a form of controlling my learning process, that is by way of:

a) I set and write according to the goals I want to achieve in writing. * (*Mention the goals you want to achieve from writing this topic!)

b) I implemented a specific strategy to improve my understanding of writing. * (*Explain the specific strategy!)

c) I modified the strategy I used according to the demands of the writing assignment. * (*Explain the results of the modification of your strategy!)

d) I discuss with peers if I have problems writing. * (*Mention what you discussed and what kind of help you expect from peers!)

32. I have a habit of using time effectively to gather writing material, because:

a) I feel good planning especially collecting written material is the key to writing.

b) I need to read before writing. * (*Mention what you read!) 
c) I feel adequate material helps in presenting quality ideas. * (*Mention examples of quality material that you use as the source of your writing!)

d) I cannot write if my writing material is slight.

33. I have a habit to always show the best performance in writing, that is by way of:

a) I do write assignments in accordance with the criteria of the text, both the structure and the rules of text language.

b) I do my work on time and avoid cheating.

c) I choose, use, and change strategies that can help me complete writing assignments. * (*Mention the strategy you choose and use to complete writing assignments!)

d) I spend most of my time completing writing assignments.

34. I have a habit of choosing, using, and replacing the strategies I use according to my writing assignments because:

a) I used a strategy that has been successful before in writing. * (*Mention the strategy you mean!)

b) I tend to use a different strategy every time I write. * (*Mention the strategy you mean!)

c) I'm the type of person who will modify various types of strategies depending on the needs of the writing task. * (*Explain the results of the modification of the strategy you used!)

d) I'm a creative person and not easily satisfied with one strategy. * (*Mention a proof that shows that you are creative!)

35. I have a habit of knowing when and why to change strategies in completing writing tasks because:

a) I realize the level of difficulty of the task and the strategies used to complete the task are not the same. * (*Mention the difficulty level of the writing assignment!)

b) I need to use the right strategy to increase my understanding of writing. * (*Mention the strategy as to what you mean!)

c) I will not use the same strategy if it does not help me in completing the task.

d) I realize my weaknesses in writing and the strategies I use are those that can cover my weaknesses in writing. * (*Mention your weaknesses in writing and what strategies can cover your weaknesses!)

36. I have a habit of using effective time and effort in completing writing assignments, for example:

a) I write down everything I know. * (*Mention an example!)

b) I set the time so that I can present each piece of writing well.

c) I made a list of achievements for writing purposes. * *Mention the list your achievements in writing!)

d) I made a list and deadline for writing assignments. * (*Mention the list and the deadline you mean!) 
37. I have a habit of doing a series of steps in writing effectively, for example:

a) I use a strategy that fits my writing assignment. * (*Mention what strategy you used!)

b) I write down what I know according to my knowledge and experience. * (*Mention the example!)

c) I plan, develop ideas, and evaluate my writing.

d) I conceive the topic and develop it into writing.

38. I have a habit of keep motivation in completing writing assignments, that is by way of:

a) I avoid things that damage my concentration. * (*Mention the example!)

b) I'm looking for an atmosphere that can increase my concentration to write. * (*Mention the example!)

c) I always discuss with peers and continue to do writing exercises and give each other suggestions for improving writing. * (*Mention what you discussed!)

d) I visit my favorite places to keep my feelings and thoughts. * (*Mention the place you mean!)

39. I have a habit of keep emotions, thoughts, and feelings while completing writing assignments, that is by way of:

a) I control excessive anxiety in writing. * (*Mention how you control your anxiety level!)

b) I avoid things that can make me worry. * (*Mention how the way you did!)

c) I control situations and conditions that are comfortable for writing. * (*Mention how you did to control situations and conditions!)

d) I'm looking for a comfortable place to protect my emotions, thoughts, and feelings while writing. * (*Mention examples of such a comfortable place!)

40. I have a habit of paying attention to the environment that can help and support the convenience of completing writing assignments, that is by way of:

a) I'm modifying my learning environment. * (*Mention the results of the learning environment modification!)

b) I changed the learning environment indoors by trying outdoors, for example in the park.

c) I and my friends are changing the class atmosphere. (*Mention the way did you do to change the atmosphere of the class!)

d) I chose accessories and posters that can increase motivation to write. * (*Mention examples of accessories and posters what you mean!) 